\title{
The Schizotypal Personality on an Alcohol Treatment Unit
}

\author{
Phillip Kroll and Colleen Ryan
}

D

SM-III restricts the diagnosis of schizophrenia to those patients demonstrating overt evidence of a thought disorder or hallucination. The study describes seven patients on an inpatient alcohol treatment unit who met the criteria for schizotypal personality. Their age, mental status exam, family history, and response to medication were compatible with a schizophrenic spectrum concept of the schizotypal personality. The prompt diagnosis and treatment of psychiatric symptoms in alcoholic schizotypal personalities would aid in their rehabilitation.

DSM-III has narrowed the diagnosis of schizophrenia by developing criteria that require explicit evidence of overt thought disorder or hallucination before the diagnosis can be made. ${ }^{1}$ Those individuals who may be preschizophrenic or mildly schizophrenic continue to exist in a diagnostic limbo which in the past was characterized by such terms as latent, pseudoneurotic, or ambulatory schizophrenia. ${ }^{2}$ The Danish adoption studies of Kety et al., have introduced the concept of the "schizophrenic spectrum" in which milder forms of schizophrenia are manifested and which seem to show a genetic relationship to schizophrenic illness. ${ }^{3}$ DSM-III has divided the "borderline syndrome" into two diagnostic entities-the schizotypal personality drawn from the schizophrenic spectrum concept and the borderline personality developed from analytic concepts elaborated by Kernberg and associated with pathological ego states and acting-out character disorder (Table 1). ${ }^{4}$ Spitzer et al. found that these two diagnoses were capable of differentiating patients with the "borderline syndrome" into two distinct groups but that there was a significant degree of overlap. ${ }^{5}$ Recently, Kendler et al. have reanalyzed the original Danish data involving the relatives of schizophrenic children who were placed for adoption and have found a significantly higher incidence of schizotypal personality disorder in the biologic relatives of probands as compared to the biologic relations of controls. ${ }^{6}$

The diagnostic difficulties outlined above are only further complicated on an alcohol treatment unit. The acute effects of alcohol and subsequent withdrawal can mimic the entire spectrum of psychiatric symptomatology. The diagnosis of alcoholism is also not in any way exclusive, and once the acute effects of alcohol on the behavior and thinking of patients abates, a heterogenous group of personality and psychiatric diagnoses remain, including other axis I or axis II

From the Alcohol Rehabilitation Unit, Ann Arbor Va Medical Center, Ann Arbor, Mich. and the Department of Psychiatry, University of Michigan Medical School, Ann Arbor. Mich.

Phillip Kroll, M.D.: Chief, Alcohol Rehabilitation Unit, Ann Arbor VA Medical Center; Assistant Professor of Psychiatry, University of Michigan Medical School: Colleen Ryan, M.D.: Staff Psychiatrist, Ann Arbor VA Medical Center. Fellow', Department of Psychiatry, University of Michigan Medical School.

Address reprint requests to Phillip Kroll, M.D., Alcohol Rehabilitation Unit, VA Medical Center Ann Arbor, Mich. 48105.

(C) 1983 by Grune \& Stratton, Inr. $0010-440 \times 183 / 2403 / 0009 / \$ 1.0010$ 
Table 1.

\begin{tabular}{|c|c|}
\hline Schizotypal Personality Disorder (301.22) & Borderline Personality Disorder (301.82) \\
\hline $\begin{array}{l}\text { The following are characteristic of the individual's } \\
\text { current and long-term functioning, are not limited to } \\
\text { episodes of illness, and cause either significant } \\
\text { impairment in social or occupational functioning or } \\
\text { subjective distress. }\end{array}$ & $\begin{array}{l}\text { The following are characteristic of the individual's } \\
\text { current and long-term functioning, are not limited to } \\
\text { episodes or illness, and cause either significant } \\
\text { impairment in social or occupational functioning or } \\
\text { subjective distress. }\end{array}$ \\
\hline
\end{tabular}

At least four of the following:

- Magicial thinking, e.g., superstitiousness, clairvoyance, telepathy, "6th sense," "others can feel my feelings" (in children and adolescents, fantasies or preoccupations).

- Ideas of reference.

- Social isolation, e.g., no close friends or confidants, social contacts limited to essential everyday tasks.

- Recurrent illusions, sensing the presence of a force or person not actually present, e.g., "I felt as if my dead mother were in the room with me," depersonalization, or derealization not associated with panic attacks

- Odd speech (without loosening of association or incoherence), e.g., speech that is digressive, vague, overelaborate, circumstantial, metaphorical.

- Inadequate rapport in face-to-face interaction due to constricted or inappropriate affect, e.g., aloof, cold.

- Suspiciousness or paranoid ideation.

- Undue social anxiety or hypersensitivity to real or imagined criticism.

Does not meet the criteria for schizophrenia.

At least five of the following are required:

- Impulsivity or unpredictability in at least two areas that are potentially self-damaging, e.g., spending, sex, gambling, substance abuse, shoplifting, overeating, physically self-damaging acts.

- A pattern of unstable and intense interpersonal relationships, e.g., marked shifts of attitude, idealization, devaluation, manipulation (consistently using others for one's own ends).

- Inappropriate, intense anger or lack of control of anger, e.g., frequent displays of temper, constant anger.

- Identity disturbance manifested by uncertainty about several issues relating to identity, such as self-image, gender identity, long-term goals or career choice, friendship patterns, values, and loyalties, e.g., "Who am I?" "I feel like I am my sister when I am good."

- Affective instability; marked shifts from normat mood to depression, irritability, or anxiety, usually lasting a few hours and only rarely more than a few days, with a return to normal mood.

- Intolerance of being alone, e.g., frantic efforts to avoid being alone, depressed when alone.

- Physically self-damaging acts, e.g., suicidal gestures, self-mutilization, recurrent accidents, or physical tights.

If under 18 , does not meet the criteria for identity disorder.

diagnoses such as manic-depressive illness, schizophrenia, or antisocial personality.

Utilizing DSM-III criteria for schizotypal personality, we reviewed the patients treated on our Alcohol Treatment Unit over the past 30 mo. A small group of anxious, schizoidal, and paranoid patients were isolated, who demonstrated a relatively refractory and distinct treatment course. Identifying the patients with schizotypal personality on an alcohol treatment unit may have importance in terms of staff expectations, hospital course, and eventual treatment. ${ }^{7}$ Many inpatient alcohol treatment units with active milieu and confrontive therapy programs already exclude patients with preexisting diagnoses of schizophrenia or organic dementia because of their inability to benefit from standard alcohol treatment modalities. Following detoxification, patients with underlying psychiatric illness who were at first considered simply alcoholic often begin to demonstrate psychiatric symptoms that call for more individualized attention. In the mass of alcohol patients, a small group of individuals wiith milder forms of severe psychiatric illness can easily be 
overlooked. The prompt diagnostic classification of such a group could lead to more appropriate support and therapy and minimize the social and physical sequelae of both their continued drinking and mental illness.

\section{METHOD}

The Alcohol Treatment Unit of the Ann Arbor VA Medical Center is a 24-bed inpatient ward with a 6-wk rehabilitation program. It is run by the Department of Psychiatry and a psychiatrist heads the treatment team. The program is more psychodynamic than didactic, although the gamut of approaches to alcohol treatment are integrated into the program-group therapy, family therapy, milieu therapy, alcohol education, Alcoholics Anonymous, and disulfiram. The 6-wk length of stay allows for complete detoxification, medical workup, and extensive psychological testing if indicated. Since the unit is part of the Department of Psychiatry, patients with known histories of schizophrenia, major depressive illness, or dementia are routinely excluded and treated on other wards. Patients with significant histories of drug use (other than occasional marijuana usage) are treated in a substance-abuse program at another VA facility. Because of limited social work staffing and the absence of halfway house capability, our population must possess minimal social support, i.e., stable housing or disability income. The indigent, resourceless alcoholic provides only a small percentage of our patient population. World War II and Korean War era veterans still form a large part of the patient population and the majority of men are either married, employed, or on disability. The average alcoholic in the program can be characterized as male, over 40 , free of overt psychosis or illicit drug use, and financially stable.

All patients included in the study and hospitalized on our unit easily met DSM-III criteria for continuous alcohol dependence (303.91). The records of 438 patients completing the entire 6-wk program between January 1, 1978 and June 30,1981 were reviewed and seven patients who met the additional criteria for schizotypal personality were located. All patients met four or more criteria for the diagnosis (Table 1). The criterion involving illusions was interpreted to include a past or current history of brief or intermittent hallucinations that do not involve alcohol use or withdrawal, i.e., hearing vague noises or one's own name called when no one else was present. Patients with prolonged hallucinatory activity were considered schizophrenic.

A total of 12 patients who demonstrated anxiety, psychotic features, and schizoidal trends in their thinking and behavior were considered for the diagnosis. Two were eliminated because of past or current diagnosis of schizophrenia. One was considered principally a borderline personality because of continued angry, antisocial, and manipulative behavior and two others were eliminated because of the persistence of depressive features along with the schizoidia.

\section{DATA}

As Table 2 illustrates, there was some diagnostic overlap with the diagnosis for borderline personality disorder and, more equivocally, for paranoid disorder or personality. Patients 5 and 6 not only were schizotypal but also qualified for the diagnosis of borderline personality. However, once sober on our unit and free of much of the social chaos involved in their drinking, these patients exhibited marked and persistent anxiety, social isolation, and paranoia. Paranoid ideation is part of the diagnostic criteria for the schizotypal personality and was most evident in patients 1,3 , and 7 . The patients, however, also had constricted affect, severe anxiety, and schizoidal social withdrawal. Their paranoid defenses were feeble attempts to deal with their constant anxiety and none had developed anything approaching a well-organized delusional system. These anxious young men appeared different from the "delusional disorder" subjects described by Winocur and other investigators who believe paranoid disorder is genetically unrelated to the schizophrenic spectrum. ${ }^{8.9}$ DSM-III briefly states that the relationship of paranoid disorder to schizophrenia 
Table 2.

\begin{tabular}{|c|c|c|c|c|}
\hline $\begin{array}{l}\text { Patient \#/Age/ Year } \\
\text { Admitted }\end{array}$ & Marital Status & Employment & Criteria Met & Mental Status \\
\hline \#1/28/1978 & $\begin{array}{l}\text { Single, never } \\
\text { married. }\end{array}$ & $\begin{array}{l}\text { Unemployed for } \\
\text { past two years. } \\
\text { Attempting to get } \\
\text { disability for } \\
\text { ankylosing } \\
\text { spondylitis. }\end{array}$ & $\begin{array}{l}\text { 2. Ideas of } \\
\text { reference } \\
\text { 3. Social isolation } \\
\text { 6. Constricted } \\
\text { affect } \\
\text { 7. Suspiciousness }\end{array}$ & $\begin{array}{l}\text { Blunted affect. Somatic } \\
\text { preoccupations with back. } \\
\text { Ideas of reference. } \\
\text { Paranoid feelings that he } \\
\text { had been outsider since } \\
\text { adolescence. Never dated } \\
\text { because of anxiety. } \\
\text { Alternative diagnosis: } \\
\text { Possible paranoid disorder. }\end{array}$ \\
\hline$\# 2 / 25 / 1978$ & Married for $6 \mathrm{yr}$. & $\begin{array}{l}\text { Unemployed for a } \\
\text { year, minimum } \\
\text { wage jobs in the } \\
\text { past. }\end{array}$ & $\begin{array}{l}\text { 2. Ideas of } \\
\text { reference } \\
\text { 3. Social isolation } \\
\text { 5. Odd speech } \\
\text { 7. Suspiciousness } \\
\text { 8. Undue social } \\
\text { anxiety }\end{array}$ & $\begin{array}{l}\text { Blunted affect, poor eye } \\
\text { contact. Ideas of reference. } \\
\text { Socially anxious. Some } \\
\text { homosexual fears. Used } \\
\text { marijuana occasionally. }\end{array}$ \\
\hline$\# 3 / 34 / 1979$ & $\begin{array}{l}\text { First marriage } \\
\text { lasted } 1 \mathrm{yr} \text {. Second } \\
\text { marriage ( } 10 \mathrm{yr} \\
\text { with two children), } \\
\text { ended while in } \\
\text { program. }\end{array}$ & $\begin{array}{l}\text { College graduate. } \\
\text { At discharge he } \\
\text { was employed as a } \\
\text { triage person for a } \\
\text { social work agency; } \\
\text { a job he soon lost. }\end{array}$ & $\begin{array}{l}\text { 2. Ideas of } \\
\text { reference } \\
\text { 3. Social isolation } \\
\text { 6. Constricted } \\
\text { affect } \\
\text { 7. Suspiciousness }\end{array}$ & $\begin{array}{l}\text { Affect flat. Ideas of } \\
\text { reference, anxiety, } \\
\text { intellectualization. } \\
\text { Paranoid jealousy. } \\
\text { Extreme social anxiety. } \\
\text { Alternative diagnosis: } \\
\text { Possible paranold disorder. }\end{array}$ \\
\hline$\# 4 / 32 / 1980$ & $\begin{array}{l}\text { Divorced twice. } \\
\text { Single for past } 5 \mathrm{yr} \text {. }\end{array}$ & $\begin{array}{l}\text { Unemployed at } \\
\text { admission. Had } \\
\text { series of } \\
\text { white-collar jobs } \\
\text { which he lost. }\end{array}$ & $\begin{array}{l}\text { 2. Ideas of } \\
\text { reference } \\
\text { 3. Social isolation } \\
\text { 6. Constricted } \\
\text { affect } \\
\text { 7. Suspiciousness }\end{array}$ & $\begin{array}{l}\text { Affect flat. Poor eye } \\
\text { contact. Extremely aloot, } \\
\text { very guarded, suspicious, } \\
\text { ideas of reference. } \\
\text { Interpersonal anxiety. }\end{array}$ \\
\hline $\begin{array}{c}\# 5 / 23 / 1976 \& \\
27 / 1970\end{array}$ & $\begin{array}{l}\text { Stormy, 4-yr } \\
\text { marriage to a } \\
\text { Korean woman. } \\
\text { Depressed over } \\
\text { current separation. }\end{array}$ & $\begin{array}{l}\text { Had worked at auto } \\
\text { plant for } 31 / 2 \mathrm{yr} \text {. }\end{array}$ & $\begin{array}{l}\text { 2. Ideas of } \\
\text { reference } \\
\text { 3. Social isolation } \\
\text { 4. Recurrent } \\
\text { illusions } \\
\text { 7. Suspiciousness } \\
\text { 8. Social anxiety }\end{array}$ & $\begin{array}{l}1976 \text { diagnosis: Alcoholism } \\
1980 \text { admission: Affect } \\
\text { flattened. Social anxiety } \\
\text { and withdrawal. Paranoid } \\
\text { ideation. Fought with } \\
\text { blacks while in the service. } \\
\text { Wife abuser. Occasionally } \\
\text { hears unexplained noises. } \\
\text { Alternative diagnosis: Met } \\
\text { criteria for borderline } \\
\text { personality. }\end{array}$ \\
\hline$\# 6 / 35 / 1981$ & $\begin{array}{l}\text { Married twice. } \\
\text { Possibility of } \\
\text { divorce from } \\
\text { second wife. }\end{array}$ & $\begin{array}{l}\text { Had been pet store } \\
\text { employee, } \\
\text { greenhouse } \\
\text { worker, and former } \\
\text { motorcycle gang } \\
\text { member. } \\
\text { Unnemployed at } \\
\text { admission. }\end{array}$ & $\begin{array}{l}\text { 2. ldeas of } \\
\text { reference } \\
\text { 3. Social isolation } \\
\text { 7. Suspiciousness } \\
\text { 8. Social anxiety }\end{array}$ & $\begin{array}{l}\text { Guarded. Many somatic } \\
\text { symptoms. Many ideas of } \\
\text { reference. Feminine } \\
\text { preoccupations and identity } \\
\text { diffusions. Mimicked } \\
\text { whatever group with which } \\
\text { he was involved. } \\
\text { Alternative diagnosis: Met } \\
\text { criteria for borderline } \\
\text { personality by history. }\end{array}$ \\
\hline
\end{tabular}


Table 2. (cont.)

\begin{tabular}{|c|c|c|c|c|}
\hline $\begin{array}{l}\text { Patient \#/ Age/ Year } \\
\text { Admitted }\end{array}$ & Marital Status & Employment & Criteria Met & Marital Status \\
\hline$\# 7 / 32 / 1981$ & $\begin{array}{l}\text { Married } 9 \text { yr with } \\
\text { two children. }\end{array}$ & $\begin{array}{l}\text { Employed as } \\
\text { skilled metal } \\
\text { worker for } 8 \mathrm{yr} .\end{array}$ & $\begin{array}{l}\text { 2. Ideas of } \\
\text { reference } \\
\text { 3. Social isolation } \\
\text { 4. Recurrent } \\
\text { illusions } \\
\text { 7. Constricted } \\
\text { affect } \\
\text { 8. Social anxiety }\end{array}$ & $\begin{array}{l}\text { Affect flat. Would not } \\
\text { socialize. Much paranoid } \\
\text { ideation. Over the years } \\
\text { had experienced one or } \\
\text { two episodes of transient } \\
\text { auditory hallucinations } \\
\text { (noises) unassociated with } \\
\text { drinking. Temper outbursts } \\
\text { at work. Hospitalized briefly } \\
\text { and treated with } \\
\text { antidepressants for a } \\
\text { "nervous breakdown." }\end{array}$ \\
\hline
\end{tabular}

remains "unclear." In no instance was it felt that the patients qualified for a diagnosis of schizophrenia or major depressive disorder during their initial admission.

Those patients diagnosed as having schizotypal personality in Table 2 significantly younger ( $30 \pm 3 \mathrm{yr}$ vs $47 \pm 11 \mathrm{yr}, p<0.001)$ than men usually hospitalized on our unit. The sample of seven patients comprised $1.6 \%$ of all patients completing the program but $4 \%$ of those under 40 . The age distribution was compatible with a diagnostic category consistent with the schizophrenic spectrum concept. The rates of marital distress, divorce, job change, and unemployment were high but no different from those of other patients on the unit. The mental status examination over the course of their hospitalization was characterized by constricted affect, severe interpersonal anxiety, ideas of reference, and paranoid ideation. There was an absence of a formal thought disorder, well-formed delusions, or overt hallucinations. These patients displayed noticeable social withdrawal in our ward milieu.

Table 3 notes other possible contributing factors to the diagnosis, i.e., family

Table 3.

\begin{tabular}{|c|c|c|c|c|}
\hline Patient \# & $\begin{array}{l}\text { Family History } \\
\text { Alcoholism and Mental } \\
\text { Illness }\end{array}$ & Psychological Testing & $\begin{array}{l}\text { Response to } \\
\text { Phenothiazines }\end{array}$ & Follow-up \\
\hline$\# 1$ & $\begin{array}{l}\text { Father drank heavily } \\
\text { and socially } \\
\text { withdrawn. No history } \\
\text { of mental illness. }\end{array}$ & $\begin{array}{l}\text { Schizoidal, emotionally } \\
\text { labile, some paranoid } \\
\text { ideation. }\end{array}$ & $\begin{array}{l}\text { Anxiety and } \\
\text { paranoid ideas } \\
\text { decreased. Ideas } \\
\text { of reference } \\
\text { decreased. }\end{array}$ & $\begin{array}{l}\text { Applying for medical } \\
\text { and psychiatric } \\
\text { disability. Living with } \\
\text { parents. Stable but } \\
\text { further deterioration in } \\
\text { socialization. } \\
\text { Abstinent. }\end{array}$ \\
\hline \#2 & $\begin{array}{l}\text { Father and mother } \\
\text { drank heavily. Father } \\
\text { schizophrenic. } \\
\text { Brother alcoholic and } \\
\text { schizotypal }\end{array}$ & $\begin{array}{l}\text { Schizoidal. No overt } \\
\text { psychosis. }\end{array}$ & $\begin{array}{l}\text { Reduced ideas of } \\
\text { reference and } \\
\text { anxiety. Thoughts } \\
\text { no longer } \\
\text { disorganized. }\end{array}$ & $\begin{array}{l}\text { Presently stable at low } \\
\text { level of functioning. } \\
\text { Readmitted } \\
\text { subsequently with } \\
\text { paranoid ideation that } \\
\text { quickly abated with } \\
\text { medication. Abstinent } \\
\text { for extended periods of } \\
\text { time. }\end{array}$ \\
\hline
\end{tabular}


Table 3. (cont.)

\begin{tabular}{|c|c|c|c|c|}
\hline Patient & $\begin{array}{l}\text { Family History } \\
\text { Alcoholism and Mental } \\
\text { Illiness }\end{array}$ & Psychological Testing & $\begin{array}{l}\text { Response to } \\
\text { Phenothiazines }\end{array}$ & Follow-up \\
\hline$\# 3$ & $\begin{array}{l}\text { Raised by mother } \\
\text { and stepfather. } \\
\text { Biologic father drank. } \\
\text { Mother and } \\
\text { steplather social } \\
\text { drinkers. }\end{array}$ & $\begin{array}{l}\text { Depressive ideation. } \\
\text { Impulsive, egocentric. } \\
\text { Impaired reality testing. } \\
\text { Paranoid ideation, } \\
\text { sexual confusion. }\end{array}$ & $\begin{array}{l}\text { More comfortable } \\
\text { and less anxious. } \\
\text { Still aloof. When } \\
\text { phenothiazines } \\
\text { decreased, he } \\
\text { became overtly } \\
\text { paranoid. }\end{array}$ & $\begin{array}{l}\text { Continued } \\
\text { deterioration-applied } \\
\text { for psychiatric disability } \\
\text { as DSM-II } \\
\text { schizophrenic. } \\
\text { Eventually went off } \\
\text { medications and had to } \\
\text { be hospitalized with } \\
\text { ideas of reference and } \\
\text { paranoia. Currently } \\
\text { stable. }\end{array}$ \\
\hline$\# 4$ & $\begin{array}{l}\text { Father a corporate } \\
\text { auditor, had } \\
\text { manifested marked } \\
\text { paranoid jealousy } \\
\text { that led to parent's } \\
\text { divorce. }\end{array}$ & $\begin{array}{l}\text { Socially withdrawn. } \\
\text { Ego defects with } \\
\text { possibility of becoming } \\
\text { psychotic. Paranoia. } \\
\text { Low self-esteem. }\end{array}$ & $\begin{array}{l}\text { Much less anxious } \\
\text { and self- } \\
\text { conscious. } \\
\text { Improved eye } \\
\text { contact and } \\
\text { socialization. }\end{array}$ & $\begin{array}{l}\text { Stable. Somewhat } \\
\text { improved but residual } \\
\text { symptoms present. } \\
\text { Following an earlier } \\
\text { admission began } \\
\text { drinking after brief time } \\
\text { in a religious } \\
\text { commune. Currently } \\
\text { abstinent. }\end{array}$ \\
\hline$\# 5$ & $\begin{array}{l}\text { Father drank heavily, } \\
\text { was socially } \\
\text { withdrawn, and was } \\
\text { abusive to patient. }\end{array}$ & $\begin{array}{l}\text { Depressed ideation. } \\
\text { Schizoidal. Lacks } \\
\text { impulse control and } \\
\text { emotionally cold. } \\
\text { Paranoia. }\end{array}$ & $\begin{array}{l}\text { Decreased ideas of } \\
\text { reference and } \\
\text { violent outbursts. }\end{array}$ & $\begin{array}{l}\text { Drank heavily between } \\
\text { first and second } \\
\text { admission. Returned to } \\
\text { program in } 1980 \\
\text { because of marital } \\
\text { separation with marked } \\
\text { increase in overt } \\
\text { anxiety, ideas of } \\
\text { reference, and affective } \\
\text { blunting. Lost to } \\
\text { follow-up. }\end{array}$ \\
\hline$\# 6$ & $\begin{array}{l}\text { Father alcoholic. } \\
\text { Mother paranoid by } \\
\text { patient's history. } \\
\text { Brother hospitalized } \\
\text { with diagnosis of } \\
\text { schizophrenia. }\end{array}$ & $\begin{array}{l}\text { Schizoidal. Fair reality } \\
\text { testing but poor } \\
\text { impulse control. } \\
\text { Guarded. }\end{array}$ & $\begin{array}{l}\text { Decreased anxiety } \\
\text { and ideas of } \\
\text { reference. More } \\
\text { spontaneous and } \\
\text { direct in group. }\end{array}$ & Lost to follow-up. \\
\hline$\# 7$ & $\begin{array}{l}\text { Father drinks } \\
\text { socially. Mother is a } \\
\text { paranoid recluse by } \\
\text { patient's account. }\end{array}$ & $\begin{array}{l}\text { Schizoidal. Socially } \\
\text { withdrawn. Fair to poor } \\
\text { reality testing. History } \\
\text { of brief psychotic } \\
\text { breaks. Some paranoid } \\
\text { ideation. }\end{array}$ & $\begin{array}{l}\text { Reduced anxiety, } \\
\text { ideas of reference } \\
\text { and paranoia. }\end{array}$ & $\begin{array}{l}\text { Currently not drinking } \\
\text { and is working } \\
\text { satisfactorily. Still } \\
\text { residual symptoms of } \\
\text { paranoia and social } \\
\text { isolation. }\end{array}$ \\
\hline
\end{tabular}

history, psychological testing, response to treatment, and follow-up. Two of the patients diagnosed as schizotypal, 2 and 6 , had first-degree relatives with confirmed diagnoses of schizophrenia. According to histories obtained from the patients and brief family interviews, patients 4 and 7 had parents who demonstrated marked paranoid ideation and social withdrawal. There were no documented histories of hospitalization for major depressive disorder or mania in these families. However, there was a great deal of heavy drinking or 
alcoholism in both parents and siblings. Most fathers had modeled either excessive drinking or alcoholism. The quality of the father's drinking was isolated, continuous, and progressive, not the episodic binge drinking sometimes associated with the mood swings of affective illness. ${ }^{10}$ Although the schizotypal personality may be more prone to alcoholism than other men raised in alcoholic households, we believe that predominant etiology of the patient's alcoholism (family modeling) and their psychiatric symptomatology (genetic) are relatively independent, which may account for the dicotomy of treatment response noted in these patients.

Psychological testing, which routinely included the MMPI, WAIS, Rorschach, and TAT was consistent with the mental status examination. Schizoidia was evident and incipient psychosis was sometimes noted. Depressive ideation was more prominent on psychological testing than evident clinically. The depressions noted on the unit were mild to moderate in severity and related to the patient's social situation and myriad marital, economic, and legal problems. The depressions quickly receded with the support provided by our ward milieu and were free of guilt-ridden rumination or vegetative endogenous symptoms.

The hospital course of the alcoholic schizotypal patients reflected the nature of their two diagnoses. The patients only slowly became involved in group therapy, but quickly gave up their drinking and responded well to the supports and limits of the alcohol unit. Those with lesser degrees of paranoid ideation became compliant but anxious and withdrawn. After a diagnostic assessment that lasted from 3 to $4 \mathrm{wk}$, treatment of their psychiatric symptomatology was begun with low doses of phenothiazine medications with results that were supportive of a schizophrenic spectrum concept of their psychiatric problems. The phenothiazine medications, chosen on the basis of paticnt response and side effects, were eventually raised to the chlorpromazine equivalent of 200 to $400 \mathrm{mg}$ each day. The response to phenothiazines was clearly evident to the patient and ward staff. Not only was there a decrease in anxiety but ideas of reference disappeared, paranoid fears decreased, and the patients became more sociable. Patient 4 remarked on how he was now able to make eye contact with the therapist once he had started medication. All patients felt that the medication was helpful and that they had often been self-medicating their anxieties and brief hallucinatory episodes with alcohol. The patients were continued on phenothiazines the last few weeks of hospitalization and after discharge.

The course of the patients' illness following discharge showed a separation of treatment response between the course of their alcoholism and their psychiatric symptoms. For the average patient on our unit, a cessation of drinking is almost invariably associated with improvement in the social and interpersonal parameters of their lives. Not so with our schizotypal patients. Two patients, 5 and 6 , had more "borderline," acting-out personalities and were lost to follow-up and presumably resumed drinking. The aftercare course of the remaining patients was more related to the severity of their psychiatric symptomatology than to their previous drinking behavior. Patient 5 had experienced a progression of symptoms of anxiety and paranoia over a 4-yr period from an earlier admission 
to the index admission of diagnosis. Patient 3 was eventually recommended for disability with a DSM-II diagnosis of schizophrenia because of increasing affective constriction and paranoia. Other patients have "plateaued" in their functioning and have not shown significant improvement in their personal lives even though abstinent for long periods of time. They continue to suffer from residual symptoms of anxiety, social isolation, and paranoia.

\section{DISCUSSION}

It is very difficult for a patient to qualify for a DSM-III diagnosis of schizophrenia on our Alcohol Treatment Unit which screens out those patients with a known history of schizophrenia and psychotic thinking. An alternative diagnostic category of schizotypal personality, however, did not seem to alter clinical realities. There was an unmistakable progression of schizophrenic symptomatology in two patients and only tenuous adjustments were made by others who continue to demonstrate multiple residual schizoidal and paranoid symptoms. Although much has been made about the association of both alcoholism and borderline condition to affective illness with the subsequent employment of antidepressant and lithium therapy, the disease syndrome of alcoholism also includes schizophrenic alcoholics. ${ }^{11-13}$ Brinkley et al. have reported the treatment of five non-alcoholic women diagnosed as borderline by criteria similar to DSM-III with low dose neuroleptics, i.e., chlorpromazine equivalent 50 to $150 \mathrm{mg}$ per day. ${ }^{14}$ However, they regarded the borderline group they were describing with its somewhat unique response to neuroleptics as unrelated to schizophrenia and indicative of a separate entity. There is no doubt, however, that there is a subset of patients characterized as borderline personality or schizotypal who are mildly schizophrenic. ${ }^{15}$ How to differentiate them consistently from other patients with similar symptom clusters remains a chronic issue. The relationship of the DSM-III schizotypal personality to schizophrenia itself is still to be determined. We have described a small group of male alcoholics who also met the DSM-III criteria for schizoidal personality. Their age distribution, relatively high percentage of family members demonstrating either paranoia or a diagnosis of schizophrenia, and their response to phenothiazine medication are all consistent with a schizophrenic spectrum concept of their illness.

The limitations of the study are manifest. It is small, retrospective, and uncontrolled. In defense of the observations, however, these patients represent only a small percentage of those hospitalized on an alcohol treatment unit, extensive psychological testing served as a check on diagnosis, and the response to phenothiazine medication was dramatic. Although similar responses to antidepressant medication could not be excluded, patient 7 had a trial of antidepressant medication prior to hospitalization with little clinical benefit. It was our impression that phenothiazine medication could be used effectively in this subgroup of schizoidal paranoid men who meet the diagnostic criteria for schizotypal personality but not schizophrenia.

Since the course of the patients' illness after discharge seemed more related to their psychiatric difficulties than their drinking, we treated our patients primarily as schizotypal personalities who drank rather than as alcoholics who 
were shy. The patients' alcoholism had to be vigorously treated initially and generally responded to the standard treatment modalities. Their psychiatric difficulties proved to be more intransigent. The treatment of these patients can be made even more difficult if the alcohol treatment program does not appreciate the presence of their underlying, mildly schizophrenic symptomatology. In many programs, these patients may simply be considered unmotivated treatment failures. Their treatment is often complicated by an ideologic reluctance to utilize medication. For a small group of young alcoholic men, carefully considered treatment for their anxiety, paranoia, and social withdrawal with phenothiazine medication may aid in their alcohol rehabilitation.

\section{REFERENCES}

1. American Psychiatric Association: Committee on Nomenclature and Statistics Diagnostic and Statistical Manual of Mental Disorder (ed 3). The American Psychiatric Association, 1980. p 494

2. Stone MH: The Borderline Syndrome: Constitution, Personality and Adaptation. New York, McGraw-Hill, 1980, p 553

3. Kety SS, Rosenthal D, Wender RH, et al: Mental illness in the biological and adoptive families of adoptive schizophrenics, in Rosenthal D and Ketty SS (eds): Transmission of Schizophrenia. Oxford, Pergamon Press, 1968, pp 345-362

4. Kernberg OF: Borderline Conditions and Pathological Narcissism. New York, Jason Aronson, 1975, p 361

5. Spitzer RL, Endicott J, Gibbon M: Crossing the border into borderline personality and borderline schizophrenia. Arch Gen Psychiatry, 36:19-24, 1981

6. Kendler KS, Gruenberg AM, Strauss JS: An independent analysis of the Copenhagen Sample of the Danish Adoption Study of Schizophrenia, II: The relationship between schizotypal personality disorder and schizophrenia, 36:982-984, 1981

7. Gillis LS, Keet M: Prognostic factors and treatment results in hospitalized alcoholics. Quart J Studies Alcohol, $30: 426-437,1969$

8. Winokur G: Delusional disorder (paranoia). Compr Psychiatry, 19: 511-
521,1977

9. Kendler KS, Gruenberg AM, Strauss JS: An independent analysis of the Copenhagen Sample of the Danish Adoption Study of Schizophrenia, III: The relationship between paranoid psychosis (delusional disorder) and the schizophrenic spectrum disorder. Arch Gen Psychiatry, 38:985-987, 1981

10. Reich LH, Davis RK, Himmelhoch $\mathrm{JM}$ : Excessive alcohol use in manic depressive illness. Am J Psychiatry, 131:83-86, 1974

11. Merry J, Reynolds CM, Bailey J, et al: Prophylactic treatment of alcoholism by lithium carbonate: A controlled study. Lancet, 2;481-482, 1976

12. Rifkin A, Quitkin F, Carillo C, et al: Lithium carbonate in emotionally unstable character disorders. Arch Gen Psychiatry, 27:519-523, 1972

13. Tomsovic M: Hospitalized atcoholics patients, I: A two year study of medical, social and psychological characteristics. Hosp Community Psychiatry, 19:197-203, 1969

14. Brinkley JR, Bietman BD, Friedel RO: Low-dose neuroleptic regimens in the treatment of borderline patients. Arch Gen Psychiatry, 36:319-326, 1979

15. Grinker RR, Werble B, Drye RC: The Borderline Syndrome: A Behavioral Study of Ego Functions. New York, Basic Books, Inc., 1968, p 274 